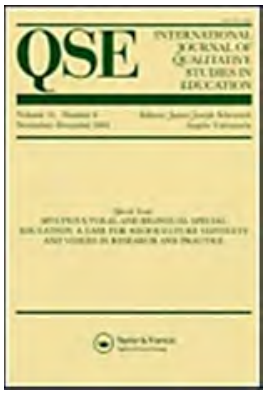

\title{
Re-turning feelings that matter using reflexivity and diffraction to think with and through a moment of rupture in activist work
}

\begin{tabular}{|r|l|}
\hline Journal: & International Journal of Qualitative Studies in Education \\
\hline Manuscript ID & TQSE-2016-0166.R1 \\
\hline Manuscript Type: & Original Paper \\
\hline Keywords: & reflexivity, diffraction, activism, posthumanism, new materialisms \\
\hline \multicolumn{2}{|c}{} \\
\hline
\end{tabular}

\section{SCHOLARONE}

Manuscripts 
Re-turning feelings that matter using reflexivity and diffraction to think with and through a moment of rupture in activist work

\author{
Author \\ School of Education and Professional Studies, Griffith University, Brisbane, \\ Australia \\ Dr Author is a Lecturer in Teacher Education - Secondary English in the \\ School of Education and Professional Studies, Griffith University, Brisbane, \\ Australia
}

Dr Author

School of Education and Professional Studies

Griffith University

(07) 37355834

s.Author@griffith.edu.au 
Re-turning feelings that matter using reflexivity and diffraction to think with and through a moment of rupture in activist work

Over the past three decades calls for alternative forms of qualitative research that require of the researcher to think deeply, differently, disruptively and diffractively have been gathering momentum. This article adds to a growing bank of possibilities for this type of work by re-turning (Barad, 2014) feelings that emerged while doing insider activist work related to issues of gender in an isolated rural Australian community. The process of re-turning feelings assists in understanding how I, and others, were being re-inscribed in this community with and through its material and discursive forces. The original five-year study (conducted three years earlier) drew on emancipatory, poststructural feminist and critical research paradigms, however, this paper takes a paradigmatic leap to fold in posthumanist and new materialist thinking as it re-turns feelings that mattered and were produced as part of the mangle of doing activist research. The paper foregrounds a different way of knowing by embracing a researcher identity that is an assemblage of feelings, thoughts, physical realities, identities, temporalities, speech acts and practices. This postmodern paradox is a superposition (Barad, 2014) of knowings and unknowings; certainties and uncertainties; power and powerlessness; an entanglement of relations and productions that are troubled and troubling, determined and indeterminate, comfortable and uncomfortable. The example on offer enmeshes and flattens the personal and political, the material and discursive and the epistemological and ontological as it cuts together-apart (Barad, 2014) past and present feelings using reflexivities of 'confounding disruptions' (Pillow, 2003, p. 192) and diffraction (Haraway, 1992; 1997; Barad, 2007; 2014). In this way I am able to know differently the effects and affects of my entanglement in the research act and world.

\section{Keywords}

post-qualitative; new materialisms; posthumanism; reflexivity; diffraction; returning; activism; gender; affect 


\section{Thinking with and beyond the reflexive turn}

As nascent forms of qualitative research gain traction by challenging normative constructs of what social science research should be and can do, the 'epistemological and ontological order of things' (St. Pierre, 2013, p. 647) is disrupted. Emerging forms of qualitative research ask us to 'think differently... within and beyond the reflexive turn...to problematize inquiry...to trouble identity and experience, and what it means to know and to tell' (Lather, 2013, p. 638). Counter-hegemonic schools of thought encompassing theories of reflexivity, affect, subjectivity, entanglement, diffraction, agential realism (Barad, 2007) and material feminisms are propagating in the borderlands to infest and infect traditional ways of thinking about thinking and being in the world. As 'the beyond of qualitative work' (Lather, 2016, p. 129) folds into the present, alternative ways of understanding the relationships between power, identities, words, bodies, differences, ontologies, epistemologies and the routines and rituals of everyday life - the intra-activity (Barad, 2007) of mutterings and matterings - gather momentum. In this 'plurality of fissions and margins' (Lather, 2016, p. 129) speech acts, practices, micro-politics, performances, temporalities, feelings, realities, technologies and nature all present as fair game for researchers intent on knowing immanently and differently who we are, what we do and who we are always already becoming (Deleuze \& Guattari, 1983).

This article adds to the growing corpus of work that has been positioned in the 'afterward' of qualitative research (Lather, 2014, p. 1). In it feelings that emerged during an activist study three years earlier are reflexively diffracted in order to see and feel otherwise. In doing so I respond to Pillow's (2003) call for researchers to produce work that offers 'more 'messy' examples, examples that may not always be successful, examples that do not seek a comfortable, transcendant end-point but leave us in the uncomfortable realities of doing engaged qualitative research' (p. 193). Through a reflexive-diffractive re-reading of feelings encountered and documented while working to unsettle limiting gender discourses and practices in my rural home town, I re-turn (Barad, 2014) feelings that mattered at the time and in so doing write myself and the research anew. This approach allows different understandings, different feelings and different subjectivities to emerge.

Barad (2014) distinguishes re-turning from returning as, 
...not...in reflecting on or going back to a past that was, but...as in turning it over and over again - iteratively intra-acting, re-diffracting, diffracting anew, in the making of new temporalities (spacetimematterings), new diffraction patterns. (p. 168)

She uses the metaphor of earthworms 'turning the soil over and over - injesting and excreting it, tunnelling through it, burrowing, all means of aerating the soil, allowing oxygen in, opening it up and breathing new life into it' (2014, p. 168) to explicate the idea further. Re-turning feelings that were produced during my activist work allows me to understand how power and emotion came to matter in the constituting of my own - and others' - personal, public and political identities and how these understandings fold into my always already becoming. According to Ahmed (2004), "emotions show us how power shapes the very surface of bodies as well as worlds' (p. 12). She claims that emotions are performative involving 'speech acts' whereby 'words are not simply cut off from bodies' (p. 13) but can be understood as adding to the affects and effects that preconfigure and reconfigure our social and cultural histories, practices and identities.

The approach I use is not research for those wanting conclusive answers to clever questions. It is not research producing comfortable and familiar tales using tried and true measures and methodologies. Instead, it is influenced by a growing body of 'postie' work (see Ahmed, 2004; Behar, 2014; Chaudhry, 1997; Jackson \& Mazzei, 2011; Minh-Ha, 1997) that offers messy examples and different ways of knowing that are tentative, uncomfortable, indeterminate and visceral. In the story that follows there are no (happy) endings. There are no winners and/or losers. There are no Earth shattering moments of scientific discovery or breakthrough. Instead, on offer is a look back-forward at encounters with-in the self-other that provide evidence of 'the interplay of difference and dominance' (Kenway, 1995, p. 42) to be found in the things that matter and make meaning in everyday life. While the paper is influenced by new materialist thinking, also to be found are traces of interpretivist and critical thinking and poststructural feminism. These residues are left behind by the original five-year activist study completed (if it is ever possible to do so) three years earlier. They attest to the relational entanglements of our methodological pasts, 
presents and futures: 'entanglements [that] are not intertwinings of separate entities, but rather irreducible relations of responsibility' (Barad, 2010, pp. 264-265).

In short, this paper re-turns feelings that mattered while conducting an earlier activist study linked to issues of gender in my rural home town. In it I draw on reflexivity and diffraction to see differently how feelings that were produced at the time became part of 'the mangle and entangled productions of subjectivity' (Jackson \& Mazzei, 2011, p. 119) that led to a significant rupturing in and from my known world and past paradigmatic allegiances. In this way the paper works subversively and incrementally to unhinge, displace, unsettle and diffract those secure spaces and comfortable corners where researchers like to gather in order to postulate and pretend that we know exactly what it is we are doing, how the world works and where we fit in it.

\section{Confounding disruptions and diffractions}

In her discussion of the virtues and vicissitudes for post-qualitative researchers of embracing reflexivity, Pillow (2003) starts by outlining typical approaches used by researchers claiming to work reflexively - 'reflexivity as recognition of self; reflexivity as recognition of other; reflexivity as truth; [and] reflexivity as transcendence' (p. 181) before moving on to problematise all four. By destabilising notions of research and researcher as rational, reasonable, reliable and knowing and replacing these with understandings of research and researcher as unknowing, uncomfortable, unsure and forever and always becoming, she makes a case for a form of reflexivity that manifests as 'practices of confounding disruptions - at times even a failure of our language and practices' (p. 192). I propose cutting together-apart (Barad, 2014) this interpretation of reflexivity, posthumanist concepts of diffraction as introduced by Haraway $(1992 ; 1997)$ and extended by Barad $(2007 ; 2014)$ with feelings produced as part of the mangle (Hekman, 2008) of doing activist research. In so doing I hope to re-diffract the data thereby birthing it anew.

To think diffractively is to reject a notion of the human subject as an essentialist being whose 'human-ness' makes it innately and solely agentic. Instead of privileging the human, Deleuze and Guattari (1983) enact posthumanist thinking to 
understand human beings as assemblages, or entanglements, of different and shifting forces and intensities. Diffraction focusses on exposing the patterns of difference, divergence and multiplicity being enacted by human agents and non-human agents and is offered as an alternative to analytical practices reifying human agency, sameness and/or binary oppositions. Human agents can incorporate bodily appearances, biological sex, gender, feelings, practices and speech acts whereas nonhuman agents assume technologies, time and nature. Barad (2014) describes diffraction as 'not a set pattern, but rather an iterative (re)configuring of patterns of differentiating-entangling' (p. 168) and draws on quantum physics to argue for the usefulness of thinking diffractively when analysing encounters - or intra-actions with/in self/others. Her concept of ontoepistemology (Barad, 2007) - or a knowing in being - thinks meaning and matter together privileging neither one nor the other. In this way Barad moves beyond a symbiotic relationship between material encounters and discursive understandings of the world to a flattening and coming together of the two: 'Practices of knowing and being are not isolable; they are mutually implicated. We don't obtain knowledge by standing outside the world - we know because we are of the world' (2007, p. 185).

Campbell (2004) claims that 'diffraction is a material-semiotic technology that produces feminist accounts of science' and goes further to argue that, 'this model of reflexive FSS [Feminist Social Science]...requires new 'material-semiotic' practices from which to construct its accounts of science' (p. 175). This paper takes up Campbell's call and Pillow's (2003) request 'to use reflexivity in a way that would continue to challenge the representations we come to while at the same time acknowledging the political need to represent and find meaning' (p.192) and puts them to work with diffraction and a re-turning of feelings that were produced during an activist study in order to know differently the ways in which power was/is being enacted through the mutterings and matterings of an isolated rural Australian community.

\section{How feelings matter}

As far back as 1995 Kenway was advocating for a form of material feminism that thought modernism and postmodernism together. She argued that ' $[\mathrm{w}] \mathrm{hile}$ 
postmodernism has made notions of authority, accountability, vision and emancipation problematic this does not necessarily mean their abandonment' (p. 43). Barad (2014) would seem to concur positing that, 'questions of temporality, materiality and justice...are crucial to and have always already been a part of discussion of diffraction/differencing' (p. 181). A recent shift in the field of material feminisms has moved from acknowledging the interdependency of the material and discursive rituals of daily life to an added engagement 'with affective physicality or human-nonhuman encounters and relations' (Hird et al., 2009, pp. 329-330). Material feminists of the 90s wanted to think the material and discursive together as a means of acknowledging the entwinement of meaning and matter in everyday practices, performances and politics and to move beyond understandings of hegemonic masculinity as a top-down structure (Fraser, 1992). New material feminists (see Barad, 2007, 2014; Hekman, 2008; Hird et al., 2009; St. Pierre, 2013) have likewise taken up the notion that 'the material is always already completely imbricated with the linguistic and discursive' (St. Pierre, 2013, p. 647) but are being influenced further by quantum physics to see the world as an entanglement of material and immaterial forces, objects and subjectivities 'constituted in the inseparable connections between the linguistic, social, political and biological' (Jackson \& Mazzei, 2011, pp. 118-119).

New materialist ways of thinking about thinking and being in the world destabilise conventional research scripts intent on establishing paradigmatic borders and biases that privilege human agency over materiality. Instead, they work to promote 'practices of confounding disruptions' (Pillow, 2003, p. 192) whereby an activist researcher - or anyone for that matter - can be a network of multiple and shifting feelings, identities and intra-activites, a 'superposition/entanglement of (seemingly) disparate parts' (Barad, 2014, p. 176). This superposition can accommodate researcher identities that are co-constituted as insider and outsider; certain and uncertain; troubled and troubling; determined and indeterminate; knowing and unknowing. Building on Deleuze and Guattari's concept of Body without Organs (1983), Mazzei (2013) introduces the notion of Voice without Organs (VwO) in which voice is de-coupled from its humanist subject and invoked as part of the 'assemblage... of human and nonhuman agents that exceeds the traditional notion of 
the individual' (p. 734). I want to take this idea and queer it further using the concept of Feelings without Organs (FwO) as a way of decoupling feelings from the human subject in order to analyse how they are constitutive of and by the mangle that is economic forces, customs, gender norms, discourses, practices, technologies, relationships, and encounters with other bodies, places and times. In adopting this thinking I hope to explore from the inside out how power gets enacted and distributed at moments of (self)rupture. This paper will draw on FwO that can be witnessed in four extracts taken from reflective journals that I wrote at the time of my doctoral research. The journal entries were originally used as a means of documenting my personal experiences of doing activist work around issues of gender. By re-turning feelings that mattered at the time, I am seeking to understand how affective forces were/are imbricated in constituting me and the shifting power relations of a small country town.

\section{Reflexivities of discomfort and diffraction}

What I propose - to borrow once more from Wanda Pillow (2003) - is the use of a concept of 'reflexivities of discomfort' (p. 188) that seek to trouble the 'parameters of comfortable research' by rebranding reflexivity to fit a postmodern and posthumanist agenda. Such an approach refuses to codify or schematisise feelings, experiences and performances or privilege human agency over non-human agency, but sets out instead to analyse and understand how our mind/body encounters with/in the self/world work together to co-construct our always already becoming in and of the world (Deleuze and Guittari, 1983). Bettez (2015) claims that the 'framing of reflexive assemblage can minimize potential tendencies to essentialize others and ourselves and maximize our awareness of multiplicities of difference, particularly as they relate to structures of oppression' (p. 5). By 'seek[ing] to know while at the same time situat[ing] this knowing as tenuous' (Pillow, 2003, p. 188) and entangled, I cut together-apart (Barad, 2014) feelings from my past and present using reflexivity and diffraction to see how power gets enacted: a revealing through feelings if you like. Barad uses the term cutting together-apart to 'trouble...the...notion of dichotomy - cutting into two- as a singular act of absolute differentiation, fracturing this from that, now from then' (p. 168). 
The cutting together-apart of old and new feelings using reflexivity and diffraction could be considered an anathema to theoretical purists, however, I contend that such unrest lies in a nervousness associated with being 'found out' overstepping some imaginary, yet heavily fortified and preordained, epistemological line. Lather (2006) troubles 'consensus' approaches to qualitative research by calling for 'unstable oppositions that shift and collapse both within and between categories' ( $p$. 36). Barad (2014), writing about identity as iterative and contingent (as opposed to fixed), could well be discussing paradigmatic identities and allegiances when she calls for a 'reworking [of] this alleged conflict into an understanding of difference not as an absolute boundary between...this and that' (p. 174). St Pierre (2013) does issue a warning to researchers re-writing and re-configuring theoretical paradigms positing that 'as we try to set aside a system of thought, an order of things, that is so powerful we can slip back into it with a single, telltale word' (p. 655).

I am fully cognizant that this paper cuts together-apart my theoretical base camps by shuffling from interpretivist, critical and emancipatory feminist designs to new materialist ones in order that I may perform my clumsy ontoepistemological dance. However, I will refrain from asking forgiveness if I misstep and/or get my worlds/words confused. If there are slippages, rather than using these as testimony to delegitimise my thinking, use them instead as evidence 'that there is no moving beyond, no leaving the 'old' behind' (Barad, 2014, p. 168). View them as one would the language practices of foreign nationals who sporadically slip back into their mother tongue when the words of their newly adopted language fail them. Instead of denouncing my slippages as aberrant and/or non-sense, I ask that they be reframed as a folding together of my past and present paradigmatic allegiances.

\section{The farmer's wife: A knowing in being}

I first felt the constraints of conventional research designs when conducting my doctoral research in an isolated rural Australian community. The population of the town and surrounding farmlands was approximately 8000. Many here identified as fifth or sixth generation farmers, farmers' wives, farm kids and farm workers. To be labelled 'a local' in this community - a signifier granted much status - I understood that you needed to be white and born here. After nearly thirty years of living in the 
community and performing the roles of teacher and farmer's wife, I was still viewed by many as an 'import'. Other signifiers assigned to me throughout my time in this community included first year teacher; young white woman; mother; middle-aged woman; experienced teacher; birdwatcher; gardener; feminist; academic; intellectual and troublemaker. These, and many more markers, have been part of the moving mangle that forms the embodiment of my feelings, gender performances, speech acts, biological sex, relationships, politics and temporality. I offer them not as a way of attempting to signify or capture who I am, have been or might become, but to locate myself as a superposition (Barad, 2014) who is a forever becoming assemblage of networked identities, knowings, doings and subjectivities. Bettez (2015) claims that, 'as we live our lives, grow and change environments, our assemblage shifts' (p. 3). I would agree and offer these sample monikers and markers as evidence of such shifts.

The community in which I conducted my activist research had been my first and only teaching position, the place where I had met and married my partner - a local farmer, raised my three children and worked as an English Head of Department at the local high school. Over my extended period of time in this community, I had developed many personal, professional and corporeal relationships producing feelings of deep connection to the people, its physical environment and its (his)stories. I had been discursively and materially constructed to 'know my position' as a white woman of relative privilege but a woman nonetheless. Normalised for me was the enactment of white male control of the public sphere (see Figure 1), finances and property ownership. In contrast, I understood females as performing roles that incorporated domestic servitude, primary care giving and cultural gatekeeping.

(Figure 1 near here)

In this community I willingly ascribed to euphemistic labels such as Cocky's wife ${ }^{1}$ and chalkie, ${ }^{2}$ without ever thinking to challenge or question their gendered overtones or the power relations inherent to them. My husband owned and managed

\footnotetext{
${ }^{1} \mathrm{~A}$ euphemisim for a farmer's wife

${ }^{2} \mathrm{~A}$ euphemism for a female teacher
} 
the property on which I lived. He was responsible for all major financial decisionmaking including such things as whether to purchase a new vehicle, have a family holiday or add an extension to the house. I had stopped working as a teacher once our children were born to be their primary caregiver and chief nurturer. This meant I was responsible for the bulk of the domestic chores including grocery shopping, garden maintenance, cooking and cleaning. I had come to accept these material and discursive rituals and realities as the natural order of things. In this world I knew my place, my responsibilities, what to expect and what was expected of me: In every sense, a knowing in being. However, during the course of conducting my doctoral research, a shift occurred and fissures began to emerge. Certain feelings I was having worked to destabilise the 'bedrock of certitude' (St Pierre, 2014) that had been my world. By the official end point of my study, the world that I thought I knew, and the person that I thought I was, had been ruptured. The known had become the unknown; the familiar, the unfamiliar; and the comfortable, the uncomfortable. I, who had once thought my self/world so certain and whole, had been profoundly disrupted. It is time to return to this moment of rupture in order to re-turn feelings that were produced and mattered at the time.

\section{Coming clean with past paradigmatic allegiances}

The larger study from which this paper draws (see Henderson \& Author, 2014: Author, 2015) began as an interpretivist study wanting to deepen understandings of why so many of the boys in this community were performing poorly at school. Preliminary research I had conducted flagged that a divergence in many boys and girls' academic and behavioural performances emerged at the age of eight and continued to widen through their schooling lives. Longitudinal data I collected and collated revealed that, upon graduating, girls from the community were consistently twice as likely as boys to make themselves eligible for direct university entrance. Initially (and in accordance with the theoretical framework I was using) I wanted to know why this was happening.

As I researched further I began to identify links between boys' schooling (under)performances, the abundance of jobs for local boys and the ways in which power was being distributed within and across the community. Evidence I collected demonstrated that many boys at the local high school were resisting schooling. This 
resistance manifested as poor academic performances, frequent absenteeism, the harassment of young female teachers and the physical and verbal bullying of students who did not conform to accepted gender norms. A discourse analysis I conducted of articles collected from the local newspaper and transcripts of interviews with community members suggested that many boys were also engaging in high-risk activities outside of school. These included participation in contact and/or highspeed sports, underage binge drinking, physical violence against others and the sexual predation of females. While girls as a statistical cohort consistently performed better at school, this all changed once school finished. Upon graduating, many of the boys would obtain local apprenticeships with considerable future earning potential. Of the girls who remained in the community, most were relegated to lower status and less well paid - traineeships. With this burgeoning knowledge came an unsettling feeling accompanied by a different way of knowing and being in my community. Increased understandings of how things were happening in my community worked to re-constitute my study and me. It/I began to veer from its/my original interpretivist intentions to become more political and emancipatory. I started to perform in ways that were deliberately disruptive of local gender constructs that I believed to be limiting community members' lives - including my own. In my emancipatory quest for social justice, I turned to the platform provided by the local newspaper. Here I wrote and published a letter problematising, what I considered to be, a particularly toxic gender message being broadcast to local youth in the form of a logo marketing an annual social event (see Figure 2). My outrage at the implicit gender messages in the logo compelled me to act. This act was entangled in the mangle of boys' schooling performances, my research, the community's power enactments, the local logo and my shifting understandings and intentions. In re-positioning myself as a community activist, my researcher identity was becoming anew.

Figure 2 near here

My public critique of the logo generated many responses. These included - but were not limited to - my mailbox being defaced with stickers of the logo, messages of support and complaint being left on my answering machine, admonishing emails from community leaders, the creation of a public blog devoted to the topic of the 
appropriateness or otherwise of the image, whispered conversations supporting my stance and complete silence on the matter from some. Over a six-month period, my propitious act resulted in me being publicly branded a 'nihilist', 'alarmist', 'absurd', 'confronting', 'old fashioned', 'a bit slow in my uptake', 'politically correct', 'humourless', 'out of control' and 'ridiculous in the extreme'. In that same period of time I was also constructed as 'brave', 'empathetic', 'respectful', 'responsible', 'so right' and informed that 'this district needs more women like you' (see Author, 2015). These words stuck to me and became embodied in my own and others' feelings and actions. Ahmed (2004) writes of words as objects that have a 'stickiness' (p. 88) about them. In this way they can stick to bodies where they work to re/preconfigure our histories, identities, practices, feelings and futures. Over days, weeks and months more and more words were produced and got stuck. They came in the form of multiple letters to the editor, full-page articles in two different newspapers, an editorial, a communal blog, a series of opinion pieces, vociferous debates and incidental discussions in bars and coffee shops and on street corners. Some words were used to condemn my stance; others to support it. The mangle of shifting feelings that I encountered during this phase of the study are depicted in Figure 3.

(Figure 3 near here)

\begin{abstract}
About two years into my study I found myself so completely entangled in the human politics of the research site that it became an ethical dilemma for me to pretend that I was somehow always in control, always rational and disaffected from the feelings I was feeling or the encounters I was having. I turned to the keeping of a journal as a way of documenting and writing through my experiences. Three years on it is to these journal entries that I return. Throughout the original study the journal entries were a way of documenting and critically reflecting on what was happening. However, this time I will draw on them to re-turn feelings that mattered using reflexivity and diffraction. By doing so I hope to make sense of how FwO were
\end{abstract}


imbricated and enmeshed in the distribution of power within and across a rural community at a moment of (self)rupture.

\section{Re-turning feelings from the past to encounter the present}

Following are four brief journal excerpts taken from - and written during - the original five-year study. They have been selected because they specifically foreground feelings. Following each of the entries are my reflexive-diffractive readings as I re-turn these feelings to produce 'afresh...the nature of, and relationship between, the material details of everyday life and broader geopolitical and socioeconomic structures' (Coole \& Frost, 2010, pp. 6-7).

\section{Extract one:}

Wednesday, February 24: I am at a friend's house for dinner.... She is no longer working in education, but is a trained primary school teacher who has recently returned from travelling overseas. She is laughing as she says, 'And haven't you stirred up a hornet's nest? I was still at the airport in the city being picked up by Adam and Barbie when they said, 'Have you read Author's letter?' They were pretty cranky, and I said, 'No, but I'd like to.' When I got to[provincial inland city] to visit the Brennans I was confronted with it again: 'Have you read Author's letter?' They even had a copy of it. It had been emailed to Ralph from someone out here. Apparently it is being emailed around quite a bit.'

I am surprised at how much attention my letter is generating. I note that it appears to be those associated with the Rugby Club-past and present-who are having the most issue with it. I find myself trying to analyse why this might be. An uncomfortableness starts to settle over me. (Author, 2015, p. 160)

In re-turning the feelings of 'uncomfortableness' and 'cranky(ness)' encountered in this entry I need to think through why and how my words were experienced by others to produce such responses. From the vantage point of a different spacetimemattering (Barad, 2007; 2010; 2014), I turn to my embodiment as 
a middle-aged white female in a community where power was linked to materialdiscursive practices authorising white male entitlement and control over the feminine/other (see Author, 2015). A public letter questioning the validity of such constructs was always going to be viewed as threatening to the known worlds of many who lived in this community - particularly those most likely to profit from the normalising of such arrangements. As a long-term local I should have known better than to challenge white male privilege. In something akin to an ontological Gordian knot, while my discomfort at the time worked to reinforce a growing sense of social displacement, it also functioned to connect me in a new way to those who would use words as tools of banishment. Ahmed (2004) claims that 'the displacement between objects works to link these objects together' (p. 66). In this way, I now see how all of us were being tied together-apart with and through our disparate feelings, words and actions.

If I consider that I was also embodied in this community as an articulate, educated, white woman of privilege, then I can understand how the public performance of my words served to intensify feelings of anger in others. Butler (2004) argues that our bodies are and are not ours; that they have a 'public dimension...constituted as a social phenomenon in the public sphere' (p. 21). The enmeshment of my middle-aged female body, professional identity, level of education, insider status and nonconformist public opinions quite likely gave a gravitas to my deeds and words that would have been moderated had I been embodied differently.

The first public response to my letter came in the form of another letter written by a white male ex-rugby club President. As is often the case in small rural communities, we had encountered each other before at our children's schooling and sporting events but were not personally or professionally close. His words functioned to diminish my own using the argument that, "[t]he fact that she takes such a dim view of the culture...suggests some unpleasant past experience' (Burr ${ }^{3}$ as cited in Author, 2015, p. 156). At the time I remember feeling threatened and intimidated by his - and others' - hostile and retaliatory responses to my letter. However, a re-

\footnotetext{
3 Pseudonym
} 
turning of his words evokes a different and quite visceral effect and affect. I feel a hot prickliness on the surface of my skin when I re-read his comments. This is accompanied by a feeling of rising indignation and anger. His implication that, because I may have been previously violated my voice is no longer reliable, attempts to publically reconstitute me as an abused, and therefore, irrational woman. Three years later, these words infuriate me.

\section{Extract two:}

Friday, April 9: I receive a phone call from Sonya's brother. He owns and runs a newspaper in a neighbouring district. His sister has told him about the ongoing logo debate in our community, and we begin talking about it and my motivations for generating it. Halfway through our conversation I realise he is taking notes. I ask him why and he tells me he is going to do a story on the controversy for his newspaper. My initial reaction is to begin censoring my words and I can't help but see the irony in suddenly being positioned as the interviewee. I can now empathise with those who have been generous enough to participate in my research. (Author, 2015, p. 169)

On returning to this telephone encounter with a white male journalist and property owner from the neighbouring district (400 kilometres further west), my first thought is to wonder if my wariness at being interviewed without knowing - and my ensuing compliance - were products of our entangled biological and gendered constructions. At the time I was feeling particularly vulnerable. My public actions had produced a number of awkward spoken and written encounters with past and present male members of the local Rugby club. Could my female embodiment and these hostile encounters have enmeshed to disarm me thus preventing my questioning of the ethics of being interviewed without consent. If the phonecall had occurred now would it have played out differently? Quite possibly. However, I recognise that this reading constitutes me as vulnerable victim and if I am to reflexively and diffractively read against myself I need to see how I can be constituted otherwise. Did not I also deceive others in my quest to achieve my political and scholarly goals? 
Was it ethical of me to publish a letter in the local newspaper challenging gender representations without disclosing to others that I did so under the dual banners of outrage at the logo's implied messages and the achievement of my research goals? Did my actions work to entangle others in research in ways that were not open and honest? Was I exploiting others for my own scholarly gains by deliberately provoking a community dialogue about local gender representations and performances? A re-turning of my feelings and actions from this time is profoundly disruptive as it works to reconfigure me from social victim to community vandal.

\section{Extract three:}

Wednesday, April 14: Sonya rings me to tell me her brother is sending 30 copies of his paper to the local Wheatville newsagent this week. I suddenly feel panicked, and express my concerns to her that members of our community have heard enough on this topic [of the logo]. We hatch a plan whereby we will buy 15 copies each as soon as the newsagent opens.

Thursday, April 15: By the next morning I feel less panicked, and ring her to cancel the plan. I resign myself to any fallout. I have rethought my actions and am starting to understand why my friend called me 'brave' for publicly challenging the logo. The story is on the front page of her brother's newspaper. It spreads over two pages. Again I am pleased to see that an image of the logo has been inserted into the article. (Author, 2015, pp. 169-170)

The shift in feelings and plans that is witnessed in these extracts demonstrates the 'dynamic and shifting entanglements of relations' (Barad, 2007, p. 224) that are always already being forged and re-forged with and through our encounters with others. Within the space of twelve hours I had re-thought a plan to 'buy 15 copies [of the newspaper]... as soon as the newsagent opens' and resigned myself to any fallout from not-acting. Feelings that mattered re-materialised to inform a decision to do nothing. In this brief temporal moment I had transitioned from one iteration of the self to another. I had reinvented myself by "thinking otherwise" (Lather, 2016, p. 
126). A repositioning that uses feelings to work from the inside out can also be witnessed in the following extract written in the final stages of my original research.

\section{Extract four:}

I have come to the crossroads. My study is all but over and it is time to start making life decisions. With what can I live and with what can I not live? If I were to leave, where would I go? If I stay, will I ever be able to truly reconnect with this community? In learning about myself I have learned that I don't necessarily fit where-or how-I thought I did. I know that it is impossible to go back-to unlearnand I know that I would not want to, but can I find-or make-a space in this community where I feel comfortable again? Where I do fit? Where I want to be? Or is it too late? Do I know too much?... I find I am making more and more trips to the city: finding reasons to leave my community-my home-more and more often....My husband tells me my study has changed me. He is right. I have grown. Become more politically literate, more intense, more attuned to seeing and exposing injustices, demanding change.... And I am not alone. Some of my female friends are also feeling it. Making comments. Have I infected them with my malcontent? Complicated their lives as well? Turned them into outsiders in their own community? I know I am responsible for starting a ripple of dissatisfaction; a desire for change. Have I betrayed my community, or enriched it? There is a bittersweet irony in knowing that I began my research journey because of my unwavering passion for, and commitment to, this community and its students, and here I am ending it by wondering whether I even belong here anymore. For the first time in my life I am considering alternatives; imagining different futures in other places...I am a different person to that which I was at the beginning of this study. (Author, 2015, pp. 213-214)

It is apparent from this entry that the doing of the research has resulted in a profound shift in my knowing and being in the world. This mind/body rupture can be 
witnessed in the continual questioning of who I am, what I have learned, where I now fit and how my research has impacted on others' lives. An intense sense of confusion and loss resonates in the mangle that is feelings, geographic shifts in location, changing relationships and new ways of knowing and being. Re-turning these feelings is still painful as my present is cut together-apart and folded into my past. I am reminded of the price that I have paid for my research; a price that includes cultural exile and social displacement. Ahmed claims that, '[I]n order to move away from attachments that are hurtful, we must first bring them into the realm of political action....the past lives in the very wounds that remain open in the present' ( $2004 \mathrm{p}$. 33). I hope she is right.

\section{An untidy ending}

Emerging forms of qualitative research are capable of being 'simultaneously chaotic, gut-wrenching, perplexing, revealing, and exhilarating' (Bettez, 2014, p. 936). Using new materialist methodologies I have re-turned feelings that mattered at a point of rupture from my known world so that I may think with and through these feelings reflexively-diffractively in order to know myself and others anew. My approach has written into existence a researcher identity that is affectively, materially, socially, politically, biologically, geographically and discursively enmeshed in her world. Drawing on material feminist and posthumanist frameworks has provided a different way of understanding the intra-actions of power, human performances and material-discursive arrangements than that offered by my original doctoral study three years earlier. In this paper I have decoupled feelings from their humanist subjects to explore how they might preconfigure and reconfigure our encounters, experiences and histories.

Interpretivist and emancipatory feminist designs have traditionally focussed on knowing more, knowing why and doing better. If I were still wedded to these approaches I would now explain why boys were doing poorly at school and list the changes that had eventuated as a result of my intervention on the world. There would be no finer conclusion to this article than to be able to write that the logo was no longer in use, that more females in my community were now represented in local government positions and that boys' academic and social performances had started to 
improve. However, there are no fairytale endings to be had here. As I write, the logo is still in use, white males still dominate the public sphere in my community, girls as a cohort still outperform boys at the local high school and I am still cut together-apart awkwardly tenanting multiple worlds - none of which are stable or secure. Instead of knowing more, knowing why and doing better, this paper has offered an example of knowing otherwise. This has been achieved via a flattening of the personal and the political, the material and the discursive and the epistemological and ontological. In doing so an 'entangled state of agencies' (Jackson and Mazzei, 2011, p. 126) has produced shifting personal, political and public performances within, across and beyond human agents and their communities - both material forces. For some involved in the original research act, our knowings and beings in the world have so profoundly ruptured and re-sedimented as to become almost unrecognisable. In returning feelings from a different spacetimemattering, it has been possible to see otherwise how the complex relational nature of power, place, gender, biological sex and time are entwined in our always already becoming in and of the world. 


\section{References}

Ahmed, S. (2004). The cultural politics of emotion. New York: Routledge

Barad, K. (2007). Meeting the universe halfway: Quantum physics and the entanglement of matter and meaning. Durham: Duke university Press.

Barad, K. (2010). Quantum entanglements and hauntological relations of inheritance: Dis/continuities, spacetime enfoldings, and justice-to-come. Derrida Today, 3(2), 240-268.

Barad, K. (2014). Diffracting diffraction: Cutting together-apart. Parallax, 20(3), 168-187.

Behar, R. (2014). The vulnerable observer: Anthropology that breaks your heart. Boston: Beacon Press.

Bettez, S. C. (2015). Navigating the complexity of qualitative research in postmodern contexts: assemblage, critical reflexivity, and communion as guides. International Journal of Qualitative Studies in Education, 28(8), 932-954.

Butler, J. (2004). Undoing gender. New York: Routledge.

Campbell, K. (2004). The promise of feminist reflexivities: Developing Donna Haraway's project for feminist science studies. Hypatia, 19(1), 162-182.

Chaudhry, L. N. (1997). Researching 'my people', researching myself: Fragments of a reflexive tale. International Journal of Qualitative Studies in Education, $10(4), 441-453$.

Coole, D., \& Frost, S. (2010). Introducing the new materialisms. In D. Coole \& S. Frost (Eds.), New materialisms: ontology, agency, and politics (pp. 1-43). Durham: Duke University Press.

Deleuze, G., \& Guattari, F. (1983). Anti-Oedipus: Schizophrenia and capitalism. Minneapolis: U of Minnesota P. 
Fraser, N. (1992). The uses and abuses of French discourse theories for feminist politics. In N. Fraser \& S. L. Bartky (Eds.), Revaluing French feminism: critical essays on difference, agency and culture (pp. 177-194). Bloomington: Indiana University Press.

Haraway, D. (1992). The promises of monsters: A regenerative politics for inappropriate/d others. In L. Grossberg, C. Nelson \& P. Treichler (Eds.), Cultural studies (pp. 295-337). London: Routledge.

Haraway, D. (1997). Modest-Witness@ Second-Millennium. FemaleMan-MeetsOncoMouse: Feminism and Technoscience. London: Psychology Press.

Hekman, S. (2008). Constructing the ballast: An ontology for feminism. In S. alaimo \& S. Hekman (Eds.), Material feminisms, (pp. 85-119). Bloomington: Indiana University Press.

Henderson, R., \& Author, (2014). A conversation about research as risky business: Making visible the invisible in rural research locations. In S. White \& M. Corbett (Eds.), Rural methodologies (pp. 119-134). NY: Routledge.

Hird, M. J., Kirby, V., Wilson, E. A., Parisi, L., Haraway, D., \& Barad, K. (2009). Feminist engagements with matter: JSTOR.

Jackson, A. Y., \& Mazzei, L. A. (2011). Thinking with theory in qualitative research: Viewing data across multiple perspectives. London: Routledge.

Kenway, J. (1995). Having a postmodernist turn or postmodernist angst: a disorder experienced by an author who is not yet dead or even close to it. In R. Smith \& P. Wexler (Eds.), After postmodernism: Education, politics, and identity (pp. 36-55). London: Falmer Press.

Lather, P. (2006). Paradigm proliferation as a good thing to think with: Teaching research in education as a wild profusion. International Journal of Qualitative Studies in Education, 19(1), 35-57.

Lather, P. (2013). Methodology-21: what do we do in the afterward? International Journal of Qualitative Studies in Education, 26(6), 634-645. 
Lather, P. (2014). To give good science: Doing qualitative research in the afterward. Qualitative Inquiry, 22(10), 1-14.

Lather, P. (2016). (Re)Thinking ontology in (post)qualitative research. Cultural Studies<->Critical Methodologies, 16(2), 125-131

Author, -. (2015). Unsettling Research: Using critical praxis and activism to create uncomfortable spaces. New York: Peter Lang.

Mazzei, L. A. (2013). A voice without organs: interviewing in posthumanist research. International Journal of Qualitative Studies in Education, 26(6), 732-740.

Minh-Ha, T. T. (1997). Not you/like you: Postcolonial women and the interlocking questions of identity and difference. Cultural Politics, 11, 415-419.

Pillow, W. (2003). Confession, catharsis, or cure? Rethinking the uses of reflexivity as methodological power in qualitative research. International Journal of Qualitative Studies in Education, 16(2), 175-196.

St. Pierre, E. A. (2013). The posts continue: Becoming. International Journal of Qualitative Studies in Education, 26(6), 646-657.

St. Pierre, E. A. (2014, December). Post qualitative inquiry. In M. Baguley (Chair), Speaking back through research. Symposium conducted at the meeting of AARE, Brisbane, Qld. 


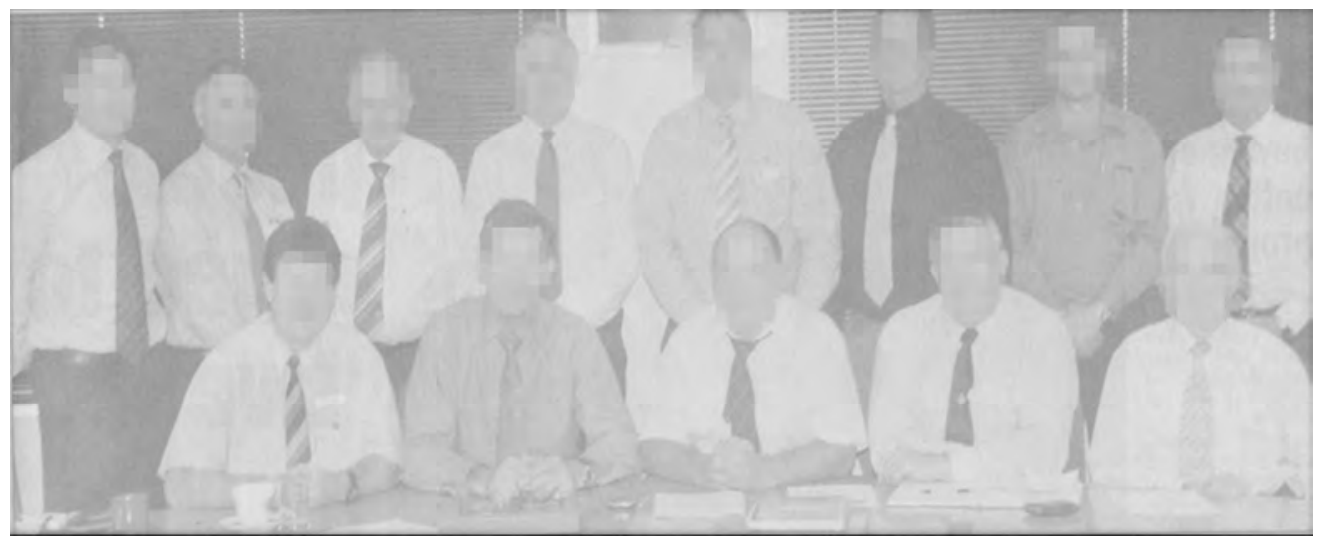

$151 \times 61 \mathrm{~mm}(300 \times 300 \mathrm{DPI})$ 


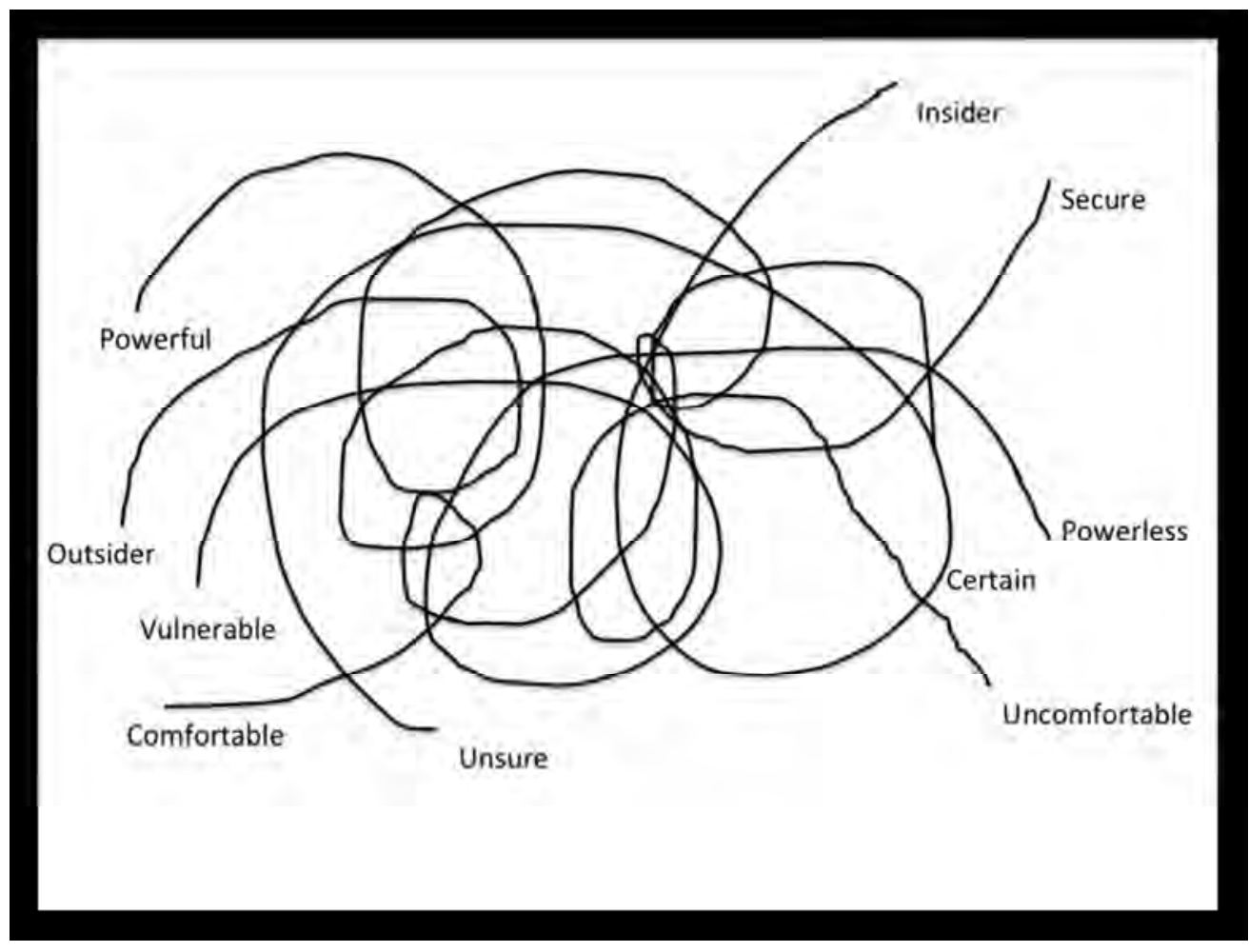

$254 \times 190 m m(72 \times 72$ DPI $)$ 


\section{좀 YOUR LETTERS:}

IS it just me or does anybody else find the logo being used by the $B \& S$ committee to advertise their annual event offensive?

You know the one: a cartoon image of an aggressive looking male emu holding a can of beer and towering over a prostrate female emu who is sporting what appears to be a "just raped" expression with legs askew, the words "plucked duck" emblazoned underneath her, and feathers flying.

I noticed the logo being used again recently to encourage new committee members to come on board. I recognise that its creators were probably "only joking" and "just having a bit of fun" and "where's my sense of humour gone?" and I have to admit that...well yes... my humour does seem

\section{"Plucked Duck" logo no joke}

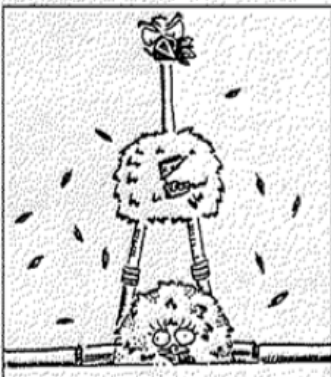

to have abandoned me with regards to this particular image.

My dilemma is: When do jokes like this become naturalised and so "normal" through constant repetition and/or over exposure that they slip into the everyday and nobody even notices them anymore or thinks to question the gender messages contained therein? Last year Australia's footballing community had a wake up call when a number of its high profile players were exposed for violent and/or misogynist acts against women.

At the time many of us were asking, "How can they possibly think that sort of behavior is OK?" But maybe it's images, dressed up in humour, like the one being used to market our own B\&S that help to make it $O K$.

Please don't get me wrong. I have nothing but admiration for those people who give tirelessly of their time and energy to make community events like the \&S happen.

I am also aware of how important these events are for maintaining a vital local economy and the generosity of committee members in giving to charitable causes.

I can also claim to have had three members of my immediate family proudly wear the Emus' colours at various times over the past 30 years.

My concerns lie not with the event or the club. They are with the sorts of messages that images like this send to our community about what is acceptable, or possibly even expected, behavior for males and females on evenings such as these.

Am I being too harsh? I would be interested in what others think. 


\section{FIGURE CAPTIONS}

Figure 1. The all-male local council

Figure 2. My public letter (Author, 2015, p. 55)

Figure 3. The mangle of feelings that mattered 